\title{
A Sociolinguistic Study of the Use of Indian Sign Language
}

\author{
Nisha Anand \\ Research Scholar \\ Centre for Linguistics, Jawaharlal Nehru University \\ New Delhi, India \\ nisha_692@yahoo.co.in
}

\begin{abstract}
This paper discusses the "Language Use" pattern of ISL by the deaf community. This paper aims to understand the vitality of sign language within the community and to foresee whether ISL is likely to be maintained in coming future. As proposed by Boehm (1997:67), "The choices people make in regard to language use reflect trend towards either language maintenance and language shift. To some extent, this reveals the vitality of the language. Fase et al. (1992:6) says that, "It has been commonly found that when the mother tongue of the minority language remains dominant in communication within the ethnic group, it can be said that mother tongue has been maintained." This survey also deals with the major issue faced by the deaf community in this speech dominant society, which is huge "communication gap" with the majority speaking people of our society.
\end{abstract}

Keywords: Indian Sign Language, Deaf Community, Domain Study, Language Use.

\section{Introduction}

Historically, the presence of deaf people has been mentioned and talked about in all human societies across time. Despite being a political, linguistic and a socially systemized 
language, Sign language has emerged as a matter of research only in the middle of the last century. Deaf people have evolved as a community having their own cultural heritage and sign language is the verbal repertoire of the community. Sign language forms the identity of the community. This speech community is unique in its way. From the perspective of the deaf, deafness must be viewed as more than just a physical disability; it is a set of attitude and behavior. The common thing which they have in their mind for forming a community is the audiological condition and sense of common oppression faced by them in a speaking and hearing dominant society. Sense of having a community generates a linguistic and social empowerment of the deaf. It is the hard work of a group of people to achieve a common set of goals which makes them united and form a community. Deaf people unite to fight for their linguistic and social rights. The Deaf community is an open-ended community; it does not have religious boundaries such as caste, class, color and beliefs to attain its membership. Membership to a Deaf community is not something which can be paternally passed to the next generation, it is a sense of understanding and experience of a person, and it has no biological connections.

William C. Stokoe (1960), enlightened the world with sign language and convinced the world that sign language is equal to spoken language or speech as a mode of communication exchange and cultural exchange. He argued that Sign language is a complete language in itself and it's just that there is a modality difference. Spoken language is articulated by mouth and perceived by our ears whereas sign language is articulated by hands and perceived by our eyes.

To sustain in a society, communication with other people is very important but deaf people in India face major communication gap. The communication gap begins from the family itself, for those of who are born in a hearing family often face this situation. As a result, often these children are aggressive because they cannot explain what they feel. For 
acquiring any language, onset of that language and social conditions play a major role. All deaf children do not experience the same social conditions therefore every deaf have their own history and background. In many cases, a deaf child born with hearing parents does not learn sign language until they come in contact with other deaf, and this contact might take many years. In rural areas often onset of sign language is very late, unless they move to urban areas and meet deaf.

This paper is completely dedicated to find out the real situation of communication gap faced by the deaf community of India and check the vitality of ISL for the deaf community. This study is important to find out the solution for this communication gap and set up language development programs for ISL.

\section{Research Methodology}

To give a clear picture of the use of language, a domain analysis method was employed. This paper is based on the survey held on language use in which thirty one deaf students and one staff of NDS (Noida Deaf Society); it is a nongovernment organization, participated. The language use pattern in nine domains are examined and analyzed respectively.

Participants were given close ended questions with multiple choice answers. The questionnaire consists of two parts. Each part has its own focus. The language used for forming questionnaire is English.

The aim of the first part of the questionnaire is to establish background information of the participants such as age, sex, mother tongue, educational background and occupation. There are in total 12 questions, which initially help to understand the background of the participant. Part II of the questionnaire focuses on the use of Indian sign language in different domains. In this part, questions were based on the domains like family, friendship, school, 
government offices, religion, neighborhood and social gathering and the people were asked to respond with the language which they use in such domains. The aim of this part was to find out the domain where ISL use is more frequent and vice-versa domains where there is minimum use of ISL. Also I wanted to see the role of domain in the development of language. It consists of 34 questions.

\subsection{Domains analyzed for this study}

Fasold (1984:183) notes that the concept of Domain was first proposed by Fishman as a way of looking language choice. According to Fishman, domains are institutional contexts in which one language is preferred over another language. Domains have certain constellation of factors such as location, activity and participant.

In this study, nine domains were analyzed. These domains were determined by interlocutors, activities and settings, as shown below in the table.

Table no 1: List of domain studied

\begin{tabular}{|l|l|l|l|}
\hline DOMAIN & INTERLOCUTORS & ACTIVITIES & SETTINGS \\
\hline Family & Parents,Spouse,Children,Siblings & & Home \\
\hline Friends & Deaf and hearing friends & & \\
\hline Neighbor & Deaf and hearing neighbor & Asking for help, & \\
\hline Market Place & Deaf and hearing shopkeeper & Buying things & \\
\hline Service providers & Government officials & Paying bills & \\
\hline Education & Teachers, classmate & & In/out classroom \\
\hline Associations & Other deaf members & Get together & \\
\hline Work Place & Colleagues & & \\
\hline
\end{tabular}




\begin{tabular}{|l|l|l|l|}
\hline Worship Place & Priest, worshipers & Offering prayers & \\
\hline
\end{tabular}

During the interaction with deaf people of NDS, It was observed that they use ISL, gestures and sometimes ASL for communication. For this study 32 deaf people were interviewed for their language use pattern in nine different domains.

Table no 2: Summary of language choice for each domain of communication

\begin{tabular}{|c|c|c|c|c|}
\hline \# & Questions & $\begin{array}{l}\text { Number of } \\
\text { Respondents }\end{array}$ & $\begin{array}{l}\text { Number } \\
\text { of } \\
\text { Response }\end{array}$ & $\%$ \\
\hline \multirow[t]{4}{*}{3} & $\begin{array}{l}\text { What language do you use while discussing with your } \\
\text { family members at dinner? }\end{array}$ & 32 & & \\
\hline & a. $\quad$ ISL & & 13 & 41 \\
\hline & b. $\quad$ ASL & & 0 & 0 \\
\hline & c. GESTURES & & 19 & 59 \\
\hline \multirow[t]{4}{*}{4} & $\begin{array}{l}\text { What language do you use while discussing a TV } \\
\text { program with your family members? }\end{array}$ & 32 & & \\
\hline & a. $\quad$ ISL & & 17 & 53 \\
\hline & b. $\quad$ ASL & & 0 & 0 \\
\hline & c. GESTURES & & 15 & 47 \\
\hline \multirow[t]{4}{*}{5} & $\begin{array}{l}\text { What language do you use while discussing a personal } \\
\text { matter with your family members? }\end{array}$ & 32 & & \\
\hline & $\begin{array}{ll}\text { a. } & \text { ISL }\end{array}$ & & 13 & 41 \\
\hline & b. $\quad$ ASL & & 0 & 0 \\
\hline & c. GESTURES & & 19 & 59 \\
\hline 6 & Among your family member to whom you are most & 32 & & \\
\hline
\end{tabular}




\begin{tabular}{|c|c|c|c|c|}
\hline & comfortable with signing? & & & \\
\hline & Father & & 0 & 0 \\
\hline & Mother & & 7 & 22 \\
\hline & c. & & 18 & 56 \\
\hline & none & & 7 & 22 \\
\hline 7 & Your Friends are: & 32 & & \\
\hline & a. All Deaf & & 8 & 25 \\
\hline & $\begin{array}{ll}\text { b. } & \text { All Hearing }\end{array}$ & & 0 & 0 \\
\hline & c. Few Deaf more Hearing & & 10 & 31 \\
\hline & d. $\quad$ Few Hearing more Deaf & & 14 & 44 \\
\hline 8 & $\begin{array}{l}\text { What Language do you use while conversing and } \\
\text { discussing general topic with friends? }\end{array}$ & 32 & & \\
\hline & a. $\quad$ ISL & & 27 & 84 \\
\hline & b. $\quad$ ASL & & 0 & 0 \\
\hline & $\begin{array}{ll}\text { c. } & \text { GESTURES }\end{array}$ & & 5 & 16 \\
\hline 9 & $\begin{array}{l}\text { What Language do you use while discussing personal } \\
\text { matters with friends? }\end{array}$ & 32 & & \\
\hline & $\begin{array}{ll}\text { a. } & \text { ISL }\end{array}$ & & 27 & 84 \\
\hline & b. ASL & & 0 & 0 \\
\hline & $\begin{array}{ll}\text { c. } & \text { GESTURES }\end{array}$ & & 5 & 16 \\
\hline 10 & $\begin{array}{l}\text { In what Language do you communicate in Social } \\
\text { Gatherings and Clubs? }\end{array}$ & 32 & & \\
\hline & a. ISL & & 32 & 100 \\
\hline & b. ASL & & 0 & 0 \\
\hline
\end{tabular}




\begin{tabular}{|c|c|c|c|c|}
\hline & c. GESTURES & & 0 & 0 \\
\hline \multirow[t]{5}{*}{11} & Are your Neighbors: & 32 & & \\
\hline & a. All Deaf & & 6 & 19 \\
\hline & b. All Hearing & & 13 & 41 \\
\hline & c. $\quad$ Few Deaf more Hearing & & 10 & 31 \\
\hline & d. Few Hearing more Deaf & & 3 & 9 \\
\hline \multirow[t]{4}{*}{12} & Whom do you visit more: & 32 & & \\
\hline & $\begin{array}{ll}\text { a. } & \text { Deaf Neighbor }\end{array}$ & & 18 & 56 \\
\hline & b. Hearing Neighbor & & 6 & 19 \\
\hline & c. Both & & 8 & 25 \\
\hline \multirow[t]{4}{*}{13} & Whom do you ask for help the most: & 32 & & \\
\hline & a. $\quad$ Deaf Neighbor & & 17 & 53 \\
\hline & b. Hearing Neighbor & & 13 & 41 \\
\hline & c. Both & & 3 & 9 \\
\hline \multirow[t]{3}{*}{14} & $\begin{array}{l}\text { Do you invite your hearing neighbor to your home for } \\
\text { any occasion? }\end{array}$ & 32 & & \\
\hline & a. $\quad$ Yes & & 28 & 88 \\
\hline & b. $\quad$ No & & 4 & 13 \\
\hline \multirow[t]{4}{*}{15} & How do you ask for help from your hearing neighbor? & 32 & & \\
\hline & a. $\quad$ ISL & & 5 & 16 \\
\hline & b. $\quad$ ASL & & 0 & 0 \\
\hline & c. GESTURES & & 27 & 84 \\
\hline \multirow[t]{2}{*}{16} & You always buy things from? & 32 & & \\
\hline & a. $\quad$ Deaf Shopkeeper & & 2 & 6 \\
\hline
\end{tabular}




\begin{tabular}{|c|c|c|c|c|}
\hline & b. $\quad$ Hearing Shopkeeper & & 30 & 94 \\
\hline \multirow[t]{5}{*}{17} & $\begin{array}{l}\text { What language do you use while buying something } \\
\text { from a hearing shopkeeper? }\end{array}$ & 32 & & \\
\hline & a. $\quad$ ISL & & 1 & 3 \\
\hline & b. $\quad$ ASL & & 0 & 0 \\
\hline & c. GESTURES & & 2 & 6 \\
\hline & d. $\quad$ YOU GIVE A LIST & & 29 & 91 \\
\hline \multirow[t]{5}{*}{18} & How do you explain your health issues to the doctor? & 32 & & \\
\hline & a. $\quad$ ISL & & 0 & 0 \\
\hline & b. $\quad$ ASL & & 0 & 0 \\
\hline & c. GESTURES & & 19 & 59 \\
\hline & $\begin{array}{ll}\text { d. YOU WRITE DO YOU YOUR PROBLEM } \\
\end{array}$ & & 13 & 41 \\
\hline \multirow[t]{5}{*}{19} & $\begin{array}{l}\text { At the railway reservation counter, how do you buy } \\
\text { ticket? }\end{array}$ & 32 & & \\
\hline & a. ISL & & 0 & 0 \\
\hline & b. $\quad$ ASL & & 0 & 0 \\
\hline & c. GESTURES & & 1 & 3 \\
\hline & $\begin{array}{ll}\text { d. } & \text { YOU WRITE ALL DETAILS ON PAPER }\end{array}$ & & 31 & 97 \\
\hline \multirow[t]{3}{*}{20} & You Studied in? & 32 & & \\
\hline & a. $\quad$ Deaf School & & 24 & 75 \\
\hline & b. Normal School & & 8 & 25 \\
\hline \multirow[t]{3}{*}{21} & Teachers were? & 32 & & \\
\hline & $\begin{array}{ll}\text { a. } & \text { All Normal }\end{array}$ & & 20 & 63 \\
\hline & b. All Deaf & & 0 & 0 \\
\hline
\end{tabular}




\begin{tabular}{|c|c|c|c|c|}
\hline & 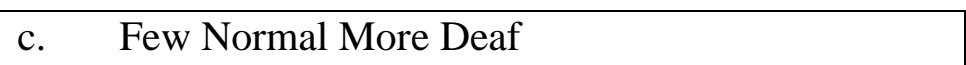 & & 5 & 16 \\
\hline & d. Few Deaf More Normal & & 7 & 22 \\
\hline \multirow[t]{4}{*}{22} & Your teacher often uses which language? & 32 & & \\
\hline & a. $\quad$ ISL & & 5 & 16 \\
\hline & b. ASL & & 0 & 0 \\
\hline & c. GESTURES & & 27 & 84 \\
\hline \multirow[t]{4}{*}{23} & You communicated with other students in? & 32 & & \\
\hline & a. $\quad$ ISL & & 23 & 72 \\
\hline & b. ASL & & 0 & 0 \\
\hline & c. GESTURES & & 9 & 28 \\
\hline \multirow[t]{5}{*}{24} & In your class, the students were? & 32 & & \\
\hline & a. ALL DEAF & & 27 & 84 \\
\hline & b. $\quad$ ALL HEARING & & 1 & 3 \\
\hline & $\begin{array}{ll}\text { c. } & \text { FEW DEAF MORE HEARING }\end{array}$ & & 2 & 6 \\
\hline & $\begin{array}{ll}\text { d. } & \text { FEW HEARING MORE DEAF }\end{array}$ & & 2 & 6 \\
\hline \multirow[t]{4}{*}{25} & $\begin{array}{l}\text { Do you often go to pay electricity bill/phone bill/water } \\
\text { bill? }\end{array}$ & 32 & & \\
\hline & $\begin{array}{ll}\text { a. } & \text { ALWAYS }\end{array}$ & & 4 & 13 \\
\hline & b. $\quad$ NEVER & & 9 & 28 \\
\hline & $\begin{array}{ll}\text { c. } & \text { SOMETIME }\end{array}$ & & 19 & 59 \\
\hline \multirow[t]{3}{*}{26} & $\begin{array}{l}\text { If yes, how do you communicate with the service } \\
\text { providers when you go to pay the bill? }\end{array}$ & 32 & & \\
\hline & $\begin{array}{ll}\text { a. } & \text { ISL } \\
\end{array}$ & & 0 & 0 \\
\hline & b. ASL & & 0 & 0 \\
\hline
\end{tabular}




\begin{tabular}{|c|c|c|c|c|}
\hline & 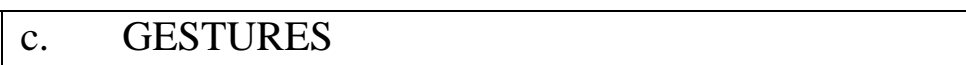 & & 6 & 19 \\
\hline & d. WRITE & & 26 & 81 \\
\hline \multirow[t]{4}{*}{27} & Do you go to the bank for any work? & 32 & & \\
\hline & a. ALWAYS & & 3 & 9 \\
\hline & b. $\quad$ NEVER & & 2 & 6 \\
\hline & $\begin{array}{ll}\text { c. } & \text { SOMETIME } \\
\end{array}$ & & 27 & 84 \\
\hline \multirow[t]{5}{*}{28} & $\begin{array}{l}\text { If yes, in which language do you explain things to the } \\
\text { bank employee? }\end{array}$ & 32 & & \\
\hline & a. ISL & & 0 & 0 \\
\hline & b. $\quad$ ASL & & 0 & 0 \\
\hline & c. GESTURE & & 3 & 9 \\
\hline & d. WRITE & & 29 & 91 \\
\hline \multirow[t]{6}{*}{29} & At your workplace are all? & 32 & & \\
\hline & DEAF & & 0 & 0 \\
\hline & b. $\quad$ HEARING & & 0 & 0 \\
\hline & FEW DEAF MORE HEARING & & 2 & 6 \\
\hline & d. $\quad$ FEW HEARING MORE DEAF & & 8 & 25 \\
\hline & $\begin{array}{ll}\text { e. } & \text { NOT APPLICABLE ( UNEMPLOYED) }\end{array}$ & & 22 & 69 \\
\hline \multirow[t]{6}{*}{30} & How your hearing staff communicate with you? & 32 & & \\
\hline & a. & & 8 & 25 \\
\hline & b. $\quad$ ASL & & 0 & 0 \\
\hline & GESTURES & & 0 & 0 \\
\hline & d. $\quad$ WRITE & & 2 & 6 \\
\hline & e. & & 22 & 69 \\
\hline
\end{tabular}




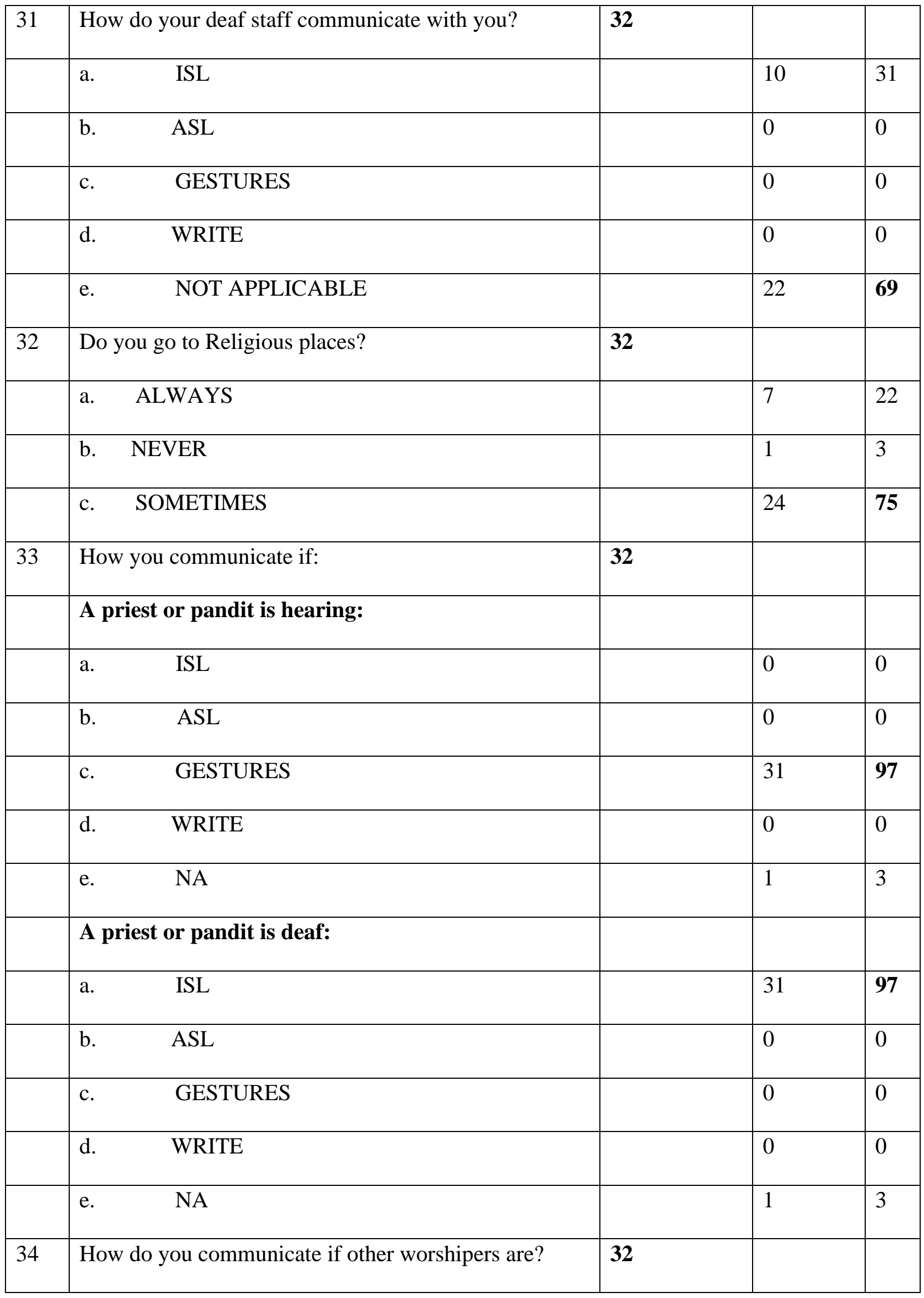




\begin{tabular}{|c|c|c|c|}
\hline \multicolumn{2}{|c|}{ DEAF } & \multirow[b]{2}{*}{31} & \multirow[b]{2}{*}{97} \\
\hline & ISL & & \\
\hline & ASL & 0 & 0 \\
\hline & GESTURES & 0 & 0 \\
\hline & WRITE & 0 & 0 \\
\hline & NA & 1 & 3 \\
\hline \multicolumn{2}{|c|}{ HEARING } & & \\
\hline & ISL & 0 & 0 \\
\hline & ASL & 0 & 0 \\
\hline & GESTURES & 31 & 97 \\
\hline & WRITE & 0 & 0 \\
\hline & NA & 1 & 3 \\
\hline
\end{tabular}

The total number of responses about language use was 640. For ISL, it is (243 out of 640) $38 \%$. For gestures, it is (219 out of 640) 34\%. Similarly for ASL, it is (0 out of 640) $0 \%$ and for others which includes communication through writing, (question no 17, 18, 19, 28, $30,31,33$ and 34 ) is ( 178 out of 640 ) is $28 \%$. The majority ( 243 out of 640 ), which is $38 \%$ of the total responses reported the use of ISL for communication situations. However, the use of gesture; (34\%) and others ; $28 \%)$ can also not be ignored. The pie chart in fig: 1 shows the use of ISL, ASL, Gestures and Others communication in the entire domain. 


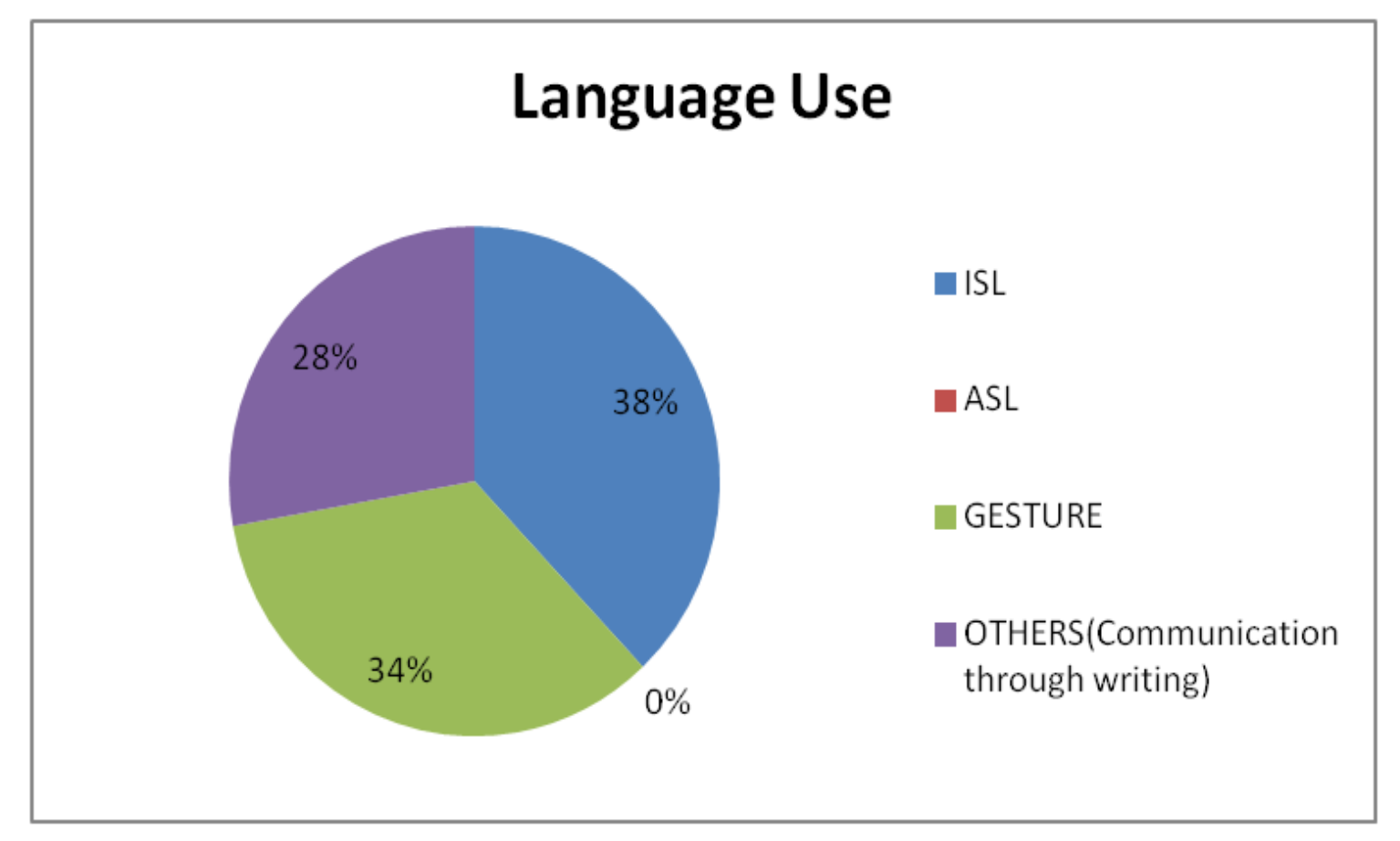

Fig: 1 Pie chart of percentage of language choice in all domains.

Although the average reported language use of ISL remains high, if we consider the choice of language use in each domain individually, it is not constant. The nine domains and their corresponding questions are as follows: family (question 3,4 \& 5), friends ( question 8 \& 9), association ( question 10 ), neighbors ( question 15 ), market ( question 17 ), Service providers (question 18,19,26 \&28 ), school (question $22 \& 23$ ), workplace ( question $30 \&$ 31), religious place ( question $33 \& 34$ ). In the deaf association, the use of ISL is highest which is $100 \%$ and it is lowest in government which is $0 \%$. Use of gestures and other mode of communication such as writing is predominantly used in different domains. 


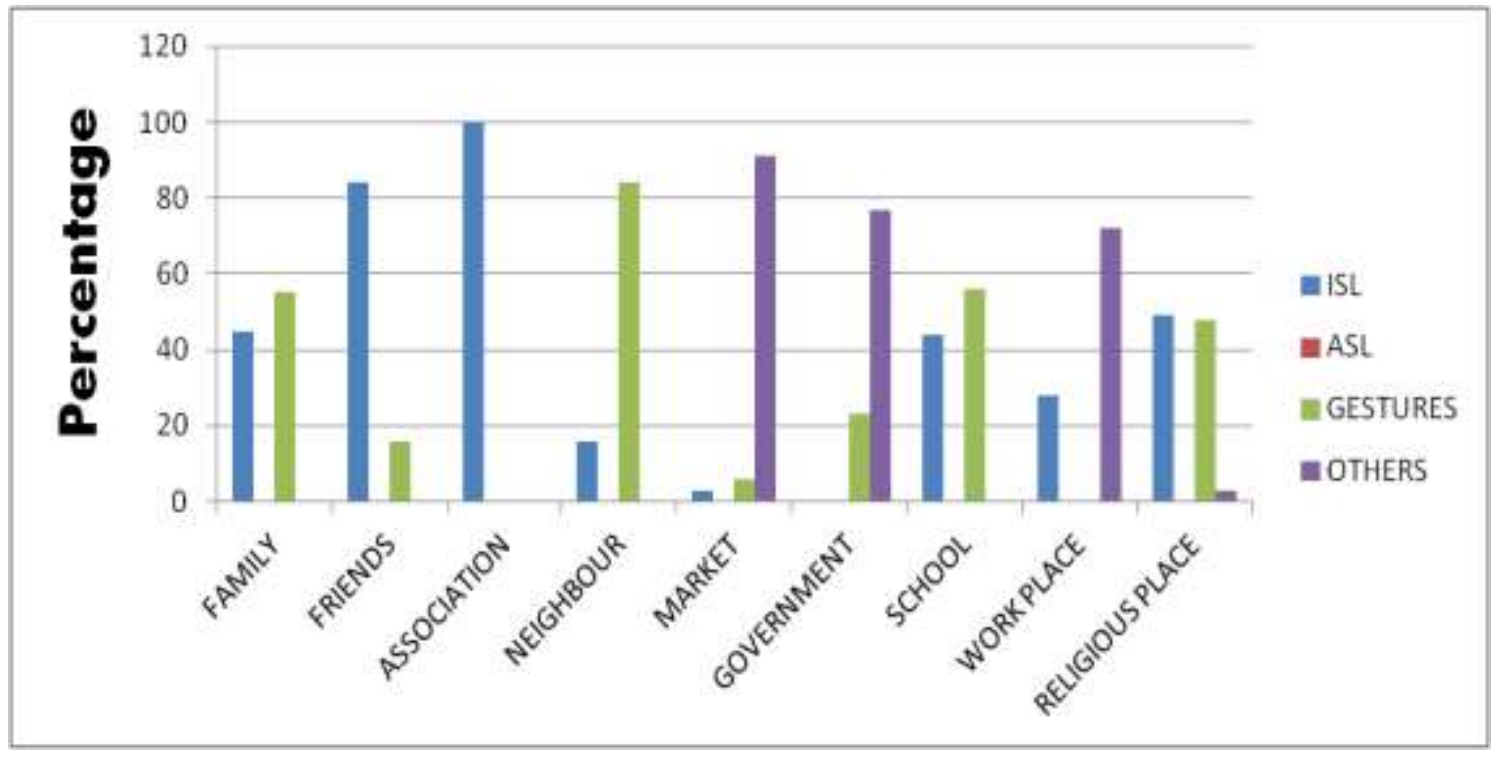

Fig: 2 Language use in nine domains

\subsubsection{Language use in an unpredictable mixed group}

Unpredictable mixed-group is a situation where the initiator of the conversation cannot predict whether the interlocutor knows ISL or not. In these domains both deaf and hearing community exists due to which one cannot predict which language should be used to talk to the interlocutor. Domains which come under unpredictable mixed group are: government, market and religious place. We will see result of language use in each domain respectively.

Service Providers:

It is interesting to see use of language by the deaf community when they go government offices like paying the electricity bill, bank or when they go to doctor for their health check up. 
Table no 3: Summary of language use in government domain

\begin{tabular}{|l|l|l|l|l|}
\hline 18 & How do you explain your health issues to the doctor? & $\mathbf{3 2}$ & & \\
\hline & a. ISL & & 0 & 0 \\
\hline & b. ASL & & 0 & 0 \\
\hline & c. GESTURES & & 19 & 59 \\
\hline 19 & At railway reservation counter, how do you buy & 32 & 13 & 41 \\
& ticket? & & & \\
\hline & a. ISL $\quad$ YSU WRITE YOUR PROBLEM & & 0 & 0 \\
\hline & b. ASL $\quad$ GESTURES & & 0 & 0 \\
\hline & c. $\quad$ YOU WRITE THE DETAILS ON PAPER & & 31 & 97 \\
\hline & d. $\quad$ & & 3 \\
\hline
\end{tabular}

\begin{tabular}{|l|l|l|l|l|}
\hline 26 & $\begin{array}{l}\text { If yes, how do you communicate with the Govt. } \\
\text { employee when you go to pay the bill? }\end{array}$ & & & \\
\hline & a. ISL & & 0 & 0 \\
\hline & b. ASL $\quad$ GESTURES & & 6 & 0 \\
\hline & c. WRITE & & 26 & 81 \\
\hline 27 & Do you go to bank for any work? & 32 & & \\
\hline & a. ALWAYS $\quad$ NEVER & 3 & 9 \\
\hline & b. $\quad$ SOMETIME & & 2 & 6 \\
\hline & c. $\quad$ & 27 & 84 \\
\hline
\end{tabular}




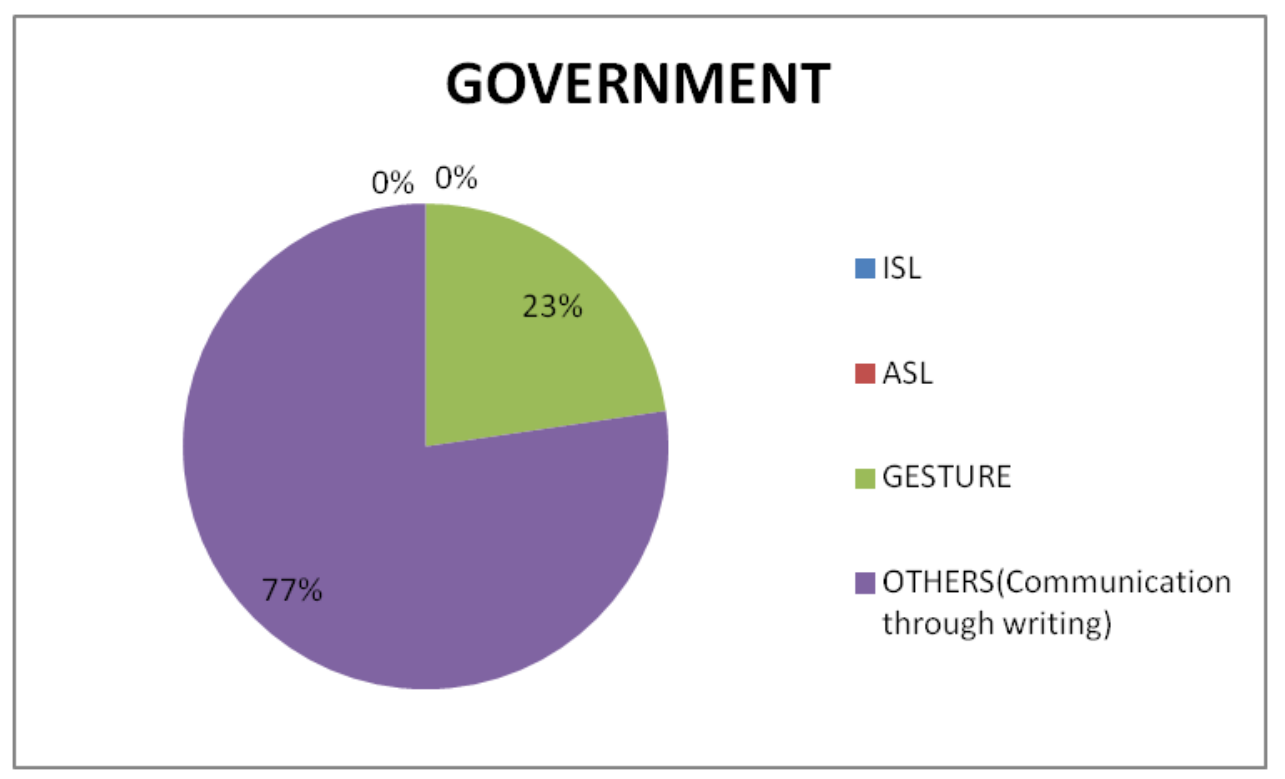

Fig: 3 Language use in government domain

It was reported that when deaf people go to different service providers for paying utility bills, purchasing tickets or doctor's visit, $77 \%$ of them communicate with their interlocutors by writing the details on a piece of paper. $23 \%$ of the respondents use gestures to communicate. ISL is never used; instead, writing is widely prevalent.

Market:

In the south-Asian language culture, it has been seen that language plays a vital role in socializing. People often buy things from those shopkeepers who speak the language of the speaker and often merchant are comfortable enough to sell their goods to mutual speakers. We will discuss the use of ISL in market areas in the following section.

Table no 4: Summary of language use at market places

\begin{tabular}{|l|l|l|l|l|}
\hline 16 & You always buy things from? & $\mathbf{3 2}$ & & \\
\hline & a. Deaf Shopkeeper & & 2 & 6 \\
\hline & b. Hearing Shopkeeper & & 30 & 94 \\
\hline
\end{tabular}




\begin{tabular}{|l|l|l|l|l|}
\hline 17 & $\begin{array}{l}\text { What language do you use while buying something } \\
\text { from hearing shopkeeper? }\end{array}$ & $\mathbf{3 2}$ & & \\
\hline & a. ISL & & 1 & 3 \\
\hline & b. ASL & & 0 & 0 \\
\hline & c. GESTURES & 2 & 6 \\
\hline & d. YOU GIVE A LIST & 29 & 91 \\
\hline
\end{tabular}

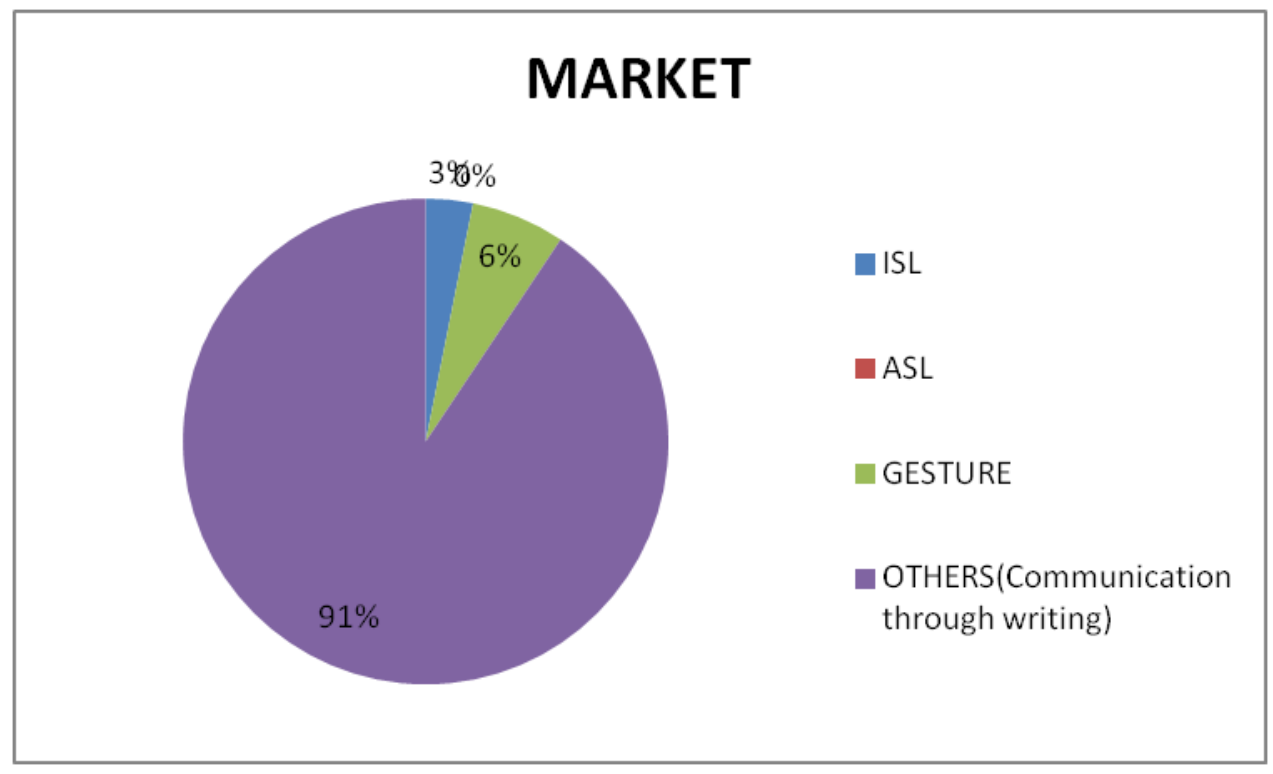

Fig: 4 Pie chart of percentage of language use at market domain

It was recorded that at market places ISL is used by only $3 \%, 6 \%$ use gestures and to the maximum $91 \%$ of communication through writing is used. Again the dominance of writing method is recorded.

Religion:

Religious places are also marked as domain where the language of the community can flourish. For example, in India, there is very little use of Sanskrit language by general public 
but during the religious activities, like chanting of mantras and other modes of worshiping, the language is used widely.

Table no 5: Summary of language use at religious places

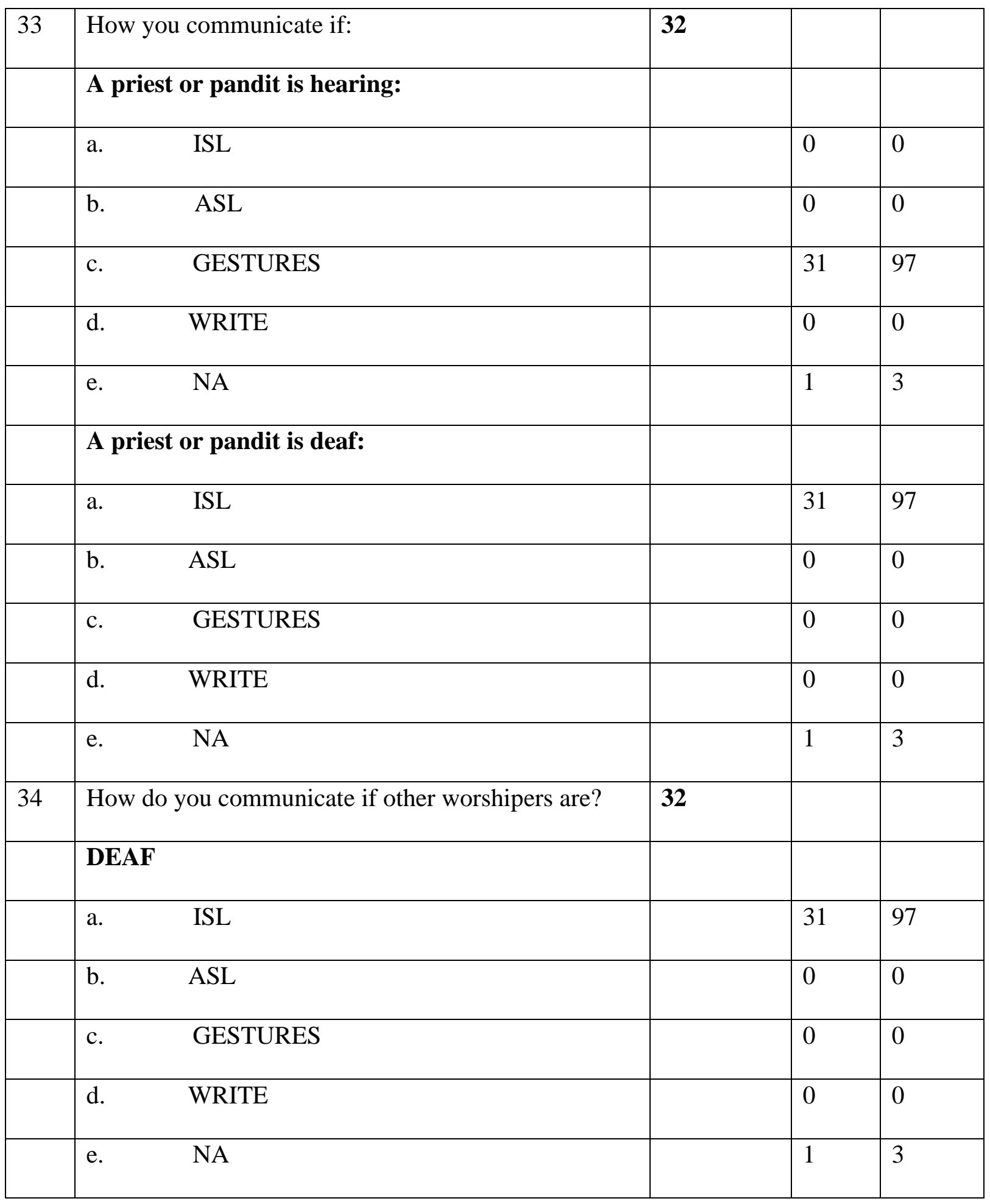




\begin{tabular}{|l|l|l|l|l|}
\hline & \multicolumn{2}{|l|}{ HEARING } & & \\
\hline & a. & ISL & 0 & 0 \\
\hline & b. & ASL & 0 & 0 \\
\hline & c. & GESTURES & 31 & 97 \\
\hline & d. & WRITE & 0 & 0 \\
\hline & e. & NA & 1 & 3 \\
\hline
\end{tabular}

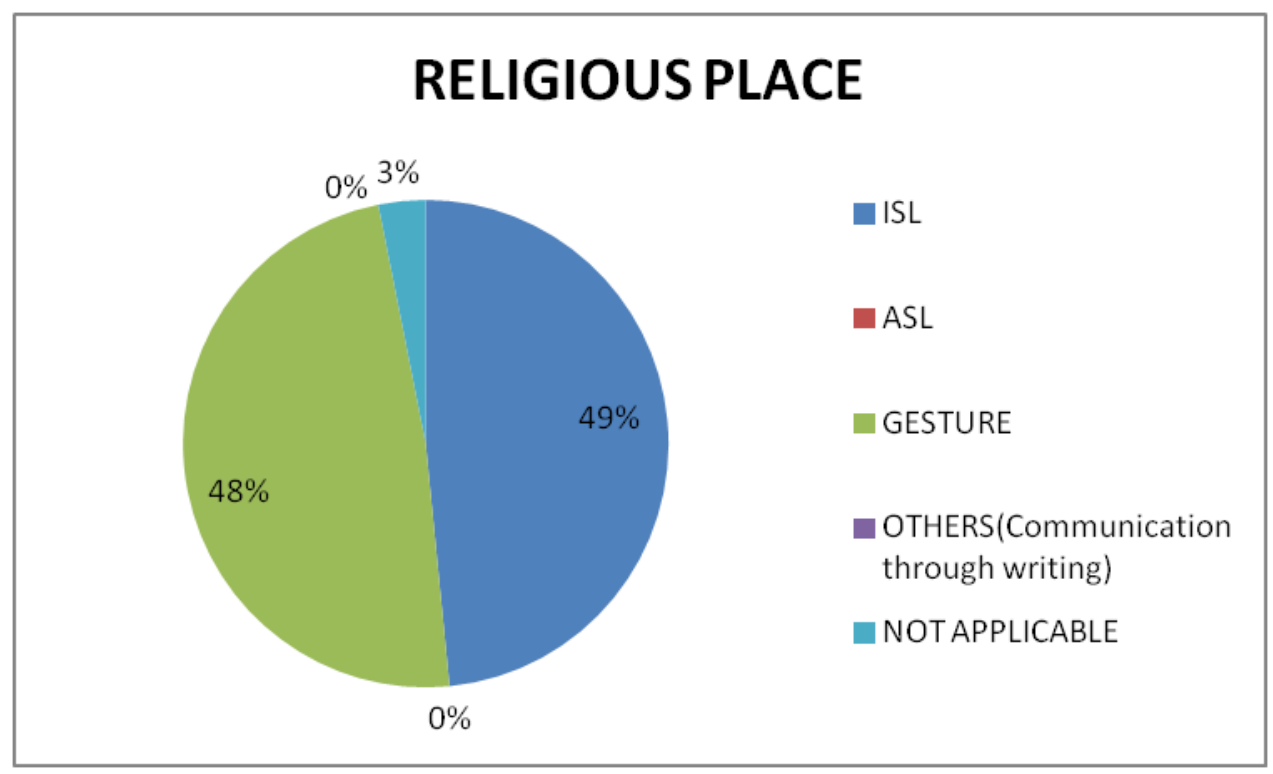

Fig: 5 Pie chart of the percentage of language use at religious places

It was recorded that on an average, the use of ISL is $49 \%$ and use of gestures is $48 \%$. If the interlocutor is deaf then the use of ISL is recorded $97 \%$.

From the results it is clear that in the unpredictable mixed group, the use of ISL is very low. For service providers, it was recorded $0 \%$, because in general service sectors employees are not trained in ISL and there are no translations/ interpretation services provided. That is why in the domain of government Deaf communicate through writing all the details in a piece of paper, and hence use of writing method scores the highest result ie $77 \%$. 
At the domain of market places use of ISL was recorded as 3\%. This use of $3 \%$ is due to the idea of inclusive employment. Few corporate companies and retail chains in India are hiring deaf people due to which use of ISL exists at few market places. But use of writing method was recorded the highest.

At religious places use of ISL was recorded as $49 \%$ and $48 \%$ use of gestures were recorded.

The use of writing communication remains high in unpredictable mixed group; there is a seldom use of ISL in this group.

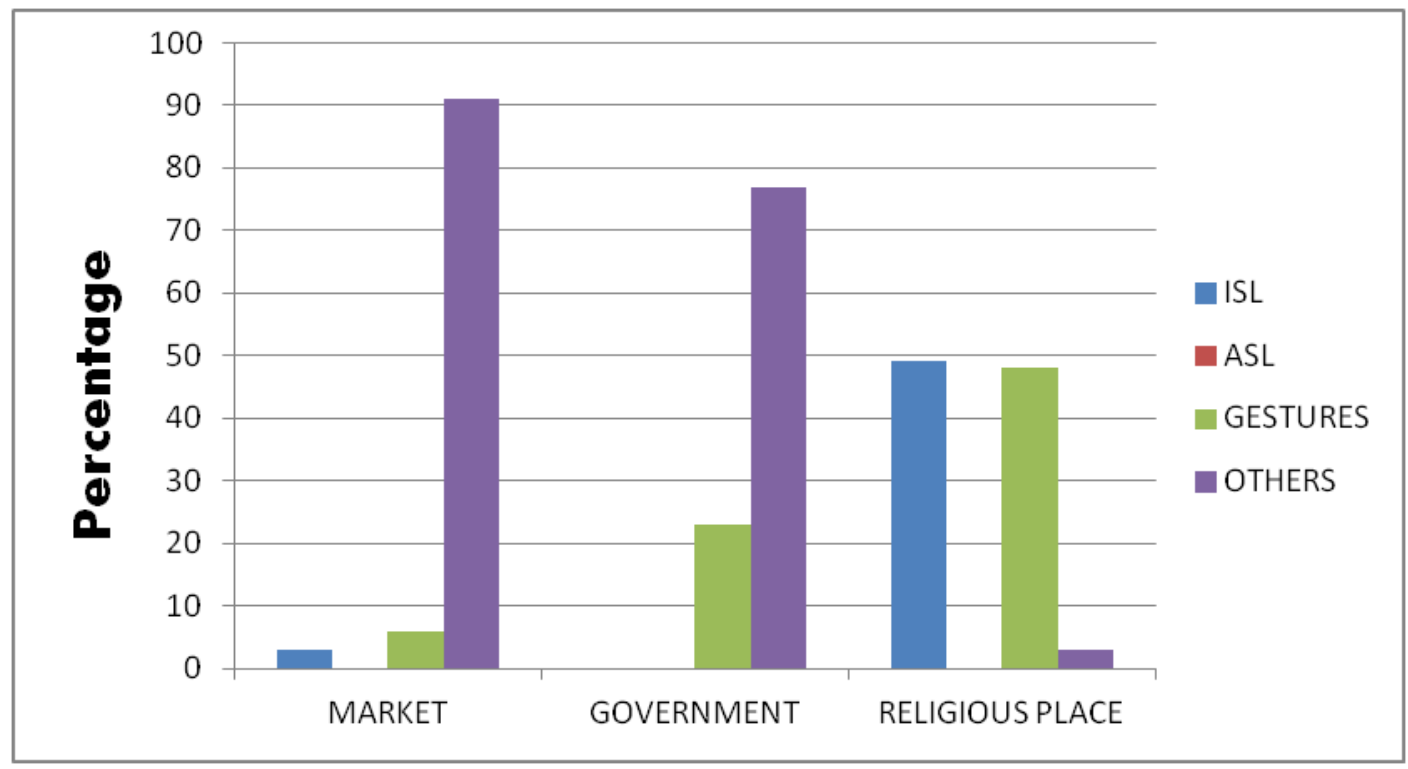

Fig: 6 Use of language use in unpredictable mixed group.

\subsubsection{Language use in Predictable Mixed Group Domain.}

Family, friends, school, work place, neighbors and deaf associations comes under predictable mixed group domain in which both deaf and hearing people co-exists. Unlike unpredictable mixed group domain, in predictable mixed group domain the initiator of the conversation knows whether the interlocutor is deaf or not, and whether they know ISL or not. For example, in school a hearing teacher wants to ask questions from a deaf student then they know in which language she/he can ask. In an office if there is a deaf employee, then 
their boss and colleagues know in what language they can communicate with that deaf employee.

We will see language use in each domain respectively:

Family:

Language use in family domain is always investigated almost in every research like language maintenance, shift and vitality (Parasher 1980, Benjamans 1998). Family domain is the fundamental domain in communication. It is the first place where a child learns, it's first language. It is also called as the intimate domain because communication takes place at the intimate level. Generally in the domain study of South Asian languages, it has been seen that family domain plays the vital role in keeping the language alive, when language has lost the battle in other domains it is the family domain which stands with the language. It is the family which passes language to its generation. Deaf family are of two types; when a deaf child is born to deaf parents, here ISL becomes native language of that child; when deaf child is born to hearing parents, in this situation child develops small group of gestures which is only understood by the parents.

Table no 6: Summary of language use in Family domain

\begin{tabular}{|l|l|l|l|l|}
\hline 2 & Is, any other Family member Deaf? & $\mathbf{3 2}$ & & \\
\hline & a. Yes & & 13 & 41 \\
\hline & b. No $\quad$ Nhat language do you use while discussing with your & $\mathbf{3 2}$ & 19 & 59 \\
\hline 3 & family members at dinner? & & & \\
\hline & a. ISL $\quad$ ASL & & 13 & 41 \\
\hline & b. & & 0 & 0 \\
\hline
\end{tabular}




\begin{tabular}{|c|c|c|c|c|}
\hline & $\begin{array}{ll}\text { c. } & \text { GESTURES }\end{array}$ & & 19 & 59 \\
\hline \multirow[t]{4}{*}{4} & $\begin{array}{l}\text { What language do you use while discussing a TV } \\
\text { program with your family members? }\end{array}$ & 32 & & \\
\hline & a. ISL & & 17 & 53 \\
\hline & b. $\quad$ ASL & & 0 & 0 \\
\hline & $\begin{array}{ll}\text { c. } & \text { GESTURES }\end{array}$ & & 15 & 47 \\
\hline \multirow[t]{4}{*}{5} & $\begin{array}{l}\text { What language do you use while discussing a } \\
\text { personal matter with your family members? }\end{array}$ & 32 & & \\
\hline & a. $\quad$ ISL & & 13 & 41 \\
\hline & b. ASL & & 0 & 0 \\
\hline & $\begin{array}{ll}\text { c. } & \text { GESTURES }\end{array}$ & & 19 & 59 \\
\hline \multirow[t]{5}{*}{6} & $\begin{array}{l}\text { Among your family member to whom you are most } \\
\text { comfortable with signing? }\end{array}$ & 32 & & \\
\hline & Father & & 0 & 0 \\
\hline & Mother & & 7 & 22 \\
\hline & Other & & 18 & 56 \\
\hline & none & & 7 & 22 \\
\hline
\end{tabular}




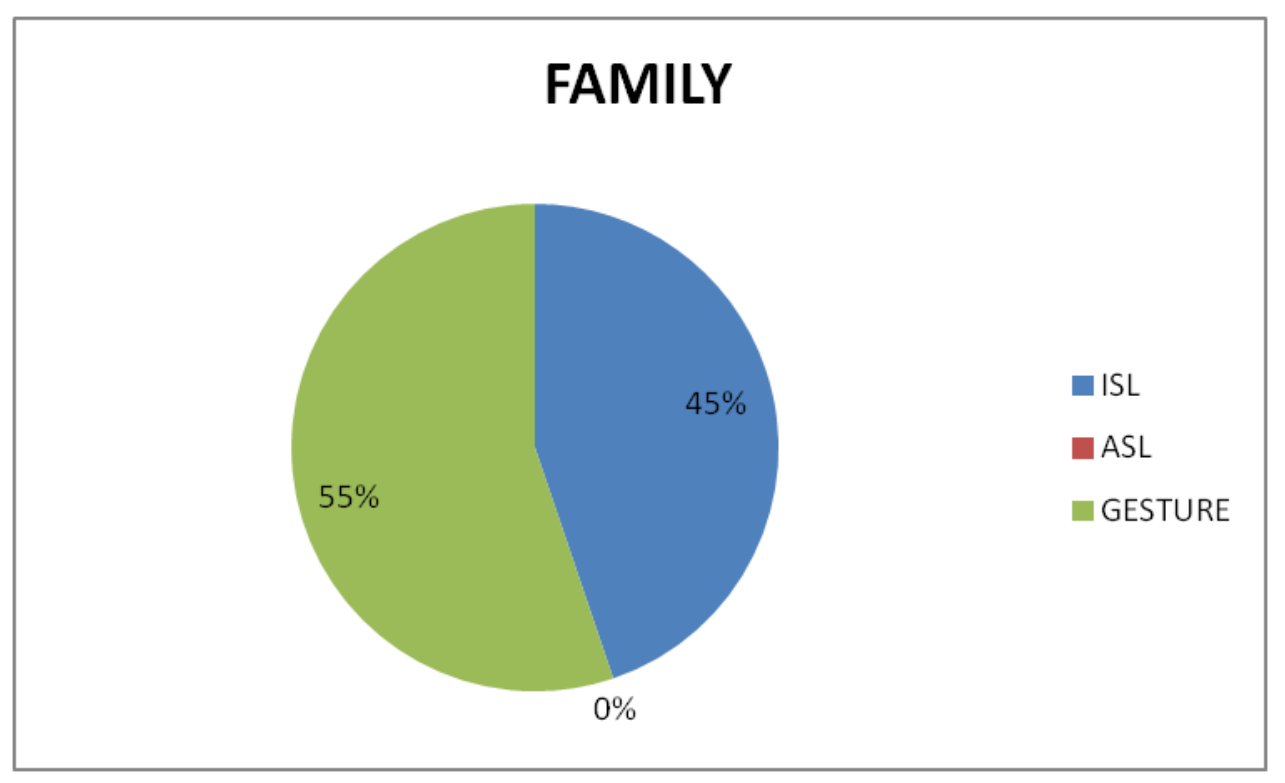

Fig: 7 Language use at family domain.

In the family domain, $45 \%$ of ISL is used and $55 \%$ gestures are used during the communication. There is no use of communication through writing and ASL.

In the deaf community, a family in which a hearing child is born to a deaf parents then the child is called as CODA (Child of deaf adult). If a hearing child has a deaf sibling then that hearing child is called SODA (Sibling of deaf adult). CODAs and SODAs are native ISL signers. Initially, when there were only a few trained sign language interpreters then these CODA and SODA used to interpret for their family and community. This is how in the form of CODA and SODA sign language flows in the family and passed on to the next generation. Development of gesture takes place when a deaf child is born to hearing parents. Hearing parents have no prior knowledge of sign language until they have a deaf child, so in order to make communication both develop a group of gestures and then parents learn ISL from their deaf child when they move out of the house and communicate with other deaf people. 
Friend:

After family, the friend domain is another intimate domain. After family members, we have friends where we can communicate on personal and intimate level. Generally, a deaf person gets friendly and intimate with another deaf. They share each other's opinion, share views and opinions and talk about personal matters with each other.

Table no 7: Summary of language use in the friend domain

\begin{tabular}{|c|c|c|c|c|}
\hline 7 & Your Friends are: & 32 & & \\
\hline & a. All Deaf & & 8 & 25 \\
\hline & b. All Hearing & & 0 & 0 \\
\hline & c. Few Deaf more Hearing & & 10 & 31 \\
\hline & $\begin{array}{ll}\text { d. } & \text { Few Hearing more Deaf }\end{array}$ & & 14 & 44 \\
\hline 8 & $\begin{array}{l}\text { What Language do you use while conversing and } \\
\text { discussing general topic with friends? }\end{array}$ & 32 & & \\
\hline & $\begin{array}{ll}\text { a. } & \text { ISL }\end{array}$ & & 27 & 84 \\
\hline & b. $\quad$ ASL & & 0 & 0 \\
\hline & c. GESTURES & & 5 & 16 \\
\hline 9 & $\begin{array}{l}\text { What Language do you use while discussing personal } \\
\text { matters with friends? }\end{array}$ & 32 & & \\
\hline & $\begin{array}{ll}\text { a. } & \text { ISL }\end{array}$ & & 27 & 84 \\
\hline & b. ASL & & 0 & 0 \\
\hline & c. GESTURES & & 5 & 16 \\
\hline
\end{tabular}




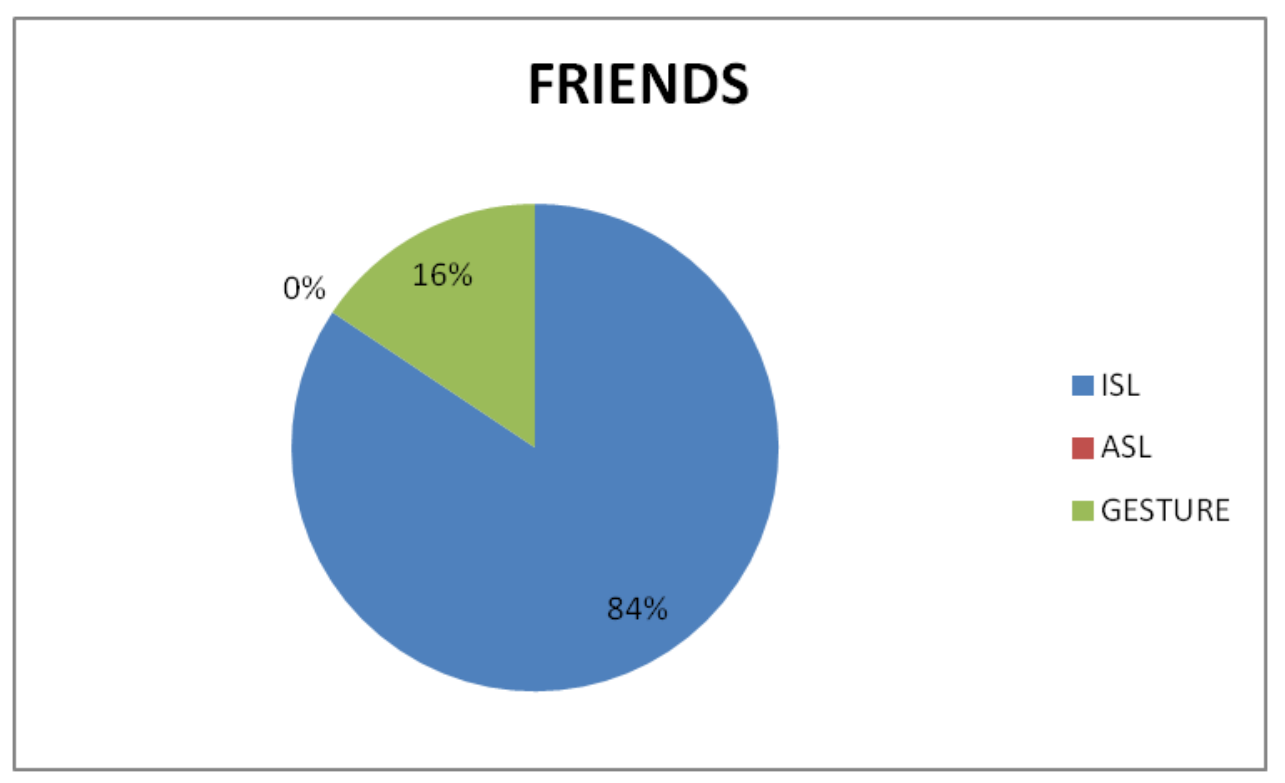

Fig: 8 Pie chart of the percentage of language use in friend domain.

Around $84 \%$ of the respondents use ISL in the friend domain, $16 \%$ use of gestures was recorded. Hence, ISL is predominantly used in friend domain.

Deaf Associations:

Over time, deaf associations have become a big platform for deaf where they socialize and participate in different activities. These associations are non-governmental organizations working for deaf rights where deaf people of that local place socialize. They conduct training programs of deaf people such as English language teaching, computer training, photography and many more so that they get a job and fit in the mainstream. Deaf associations conduct annual sports and cultural programs in which deaf people participate in full enthusiasm. Due to the initiative of these associations, India have many deaf sports persons who have represented India in Paralympics, and many deaf people have successfully got jobs. These associations are run by both deaf and hearing people. 
Table no 8: Summary of language use in Association domain

\begin{tabular}{|l|l|l|l|l|}
\hline 10 & $\begin{array}{l}\text { In what Language do you communicate in Social } \\
\text { Gatherings and Clubs? }\end{array}$ & & \\
\hline & a. ISL & & 32 & 100 \\
\hline & b. ASL & 0 & 0 \\
\hline & c. GESTURES & & 0 & 0 \\
\hline
\end{tabular}

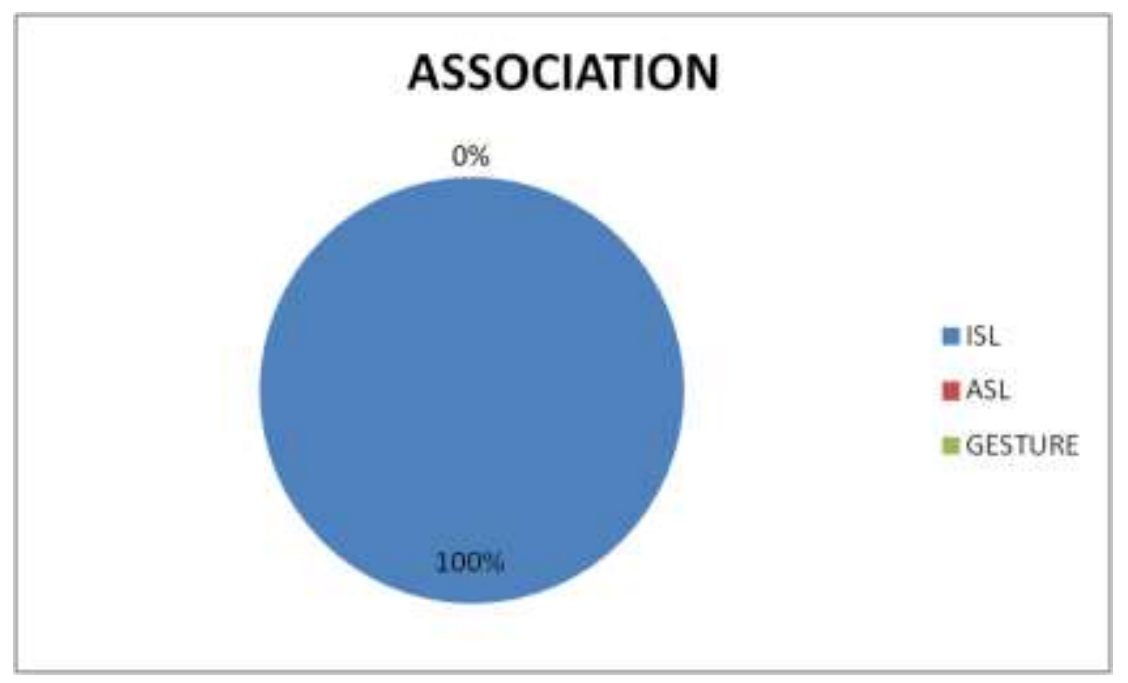

Fig: 9 Pie chart representing percentage of language use in Deaf association domain

$100 \%$ use of ISL is recorded in the association domain by the respondents. In other words, order to be a part of deaf associations one must know ISL.

Neighbor:

In the research of language use, neighbors as a domain play a vital role for language learning and development. We often socialize with those neighbors who speak same language and also learn their language if they speak any other language. A child learns the local language while playing with their neighbor's kid. 
Table no 9: Summary of language use in neighbor domain

\begin{tabular}{|c|c|c|c|c|}
\hline \multirow[t]{2}{*}{11} & Are your Neighbors: & \multirow[t]{2}{*}{32} & \multirow[b]{2}{*}{6} & \multirow[b]{2}{*}{19} \\
\hline & a. $\quad$ All Deaf & & & \\
\hline & b. All Hearing & & 13 & 41 \\
\hline & c. $\quad$ Few Deaf more Hearing & & 10 & 31 \\
\hline & d. Few Hearing more Deaf & & 3 & 9 \\
\hline \multirow[t]{4}{*}{12} & At whose do you visit more: & 32 & & \\
\hline & a. Deaf Neighbor & & 18 & 56 \\
\hline & b. Hearing Neighbor & & 6 & 19 \\
\hline & c. Both & & 8 & 25 \\
\hline \multirow[t]{4}{*}{13} & Whom do you ask for help most: & 32 & & \\
\hline & a. Deaf Neighbor & & 17 & 53 \\
\hline & b. Hearing Neighbor & & 13 & 41 \\
\hline & c. Both & & 3 & 9 \\
\hline \multirow[t]{3}{*}{14} & $\begin{array}{l}\text { Do you invite your hearing neighbor to your home for } \\
\text { any Occasion? }\end{array}$ & 32 & & \\
\hline & a. $\quad$ Yes & & 28 & 88 \\
\hline & b. No & & 4 & 13 \\
\hline \multirow[t]{4}{*}{15} & How do you ask for help from your hearing neighbor? & 32 & & \\
\hline & a. $\quad$ ISL & & 5 & 16 \\
\hline & b. $\quad$ ASL & & 0 & 0 \\
\hline & c. GESTURES & & 27 & 84 \\
\hline
\end{tabular}




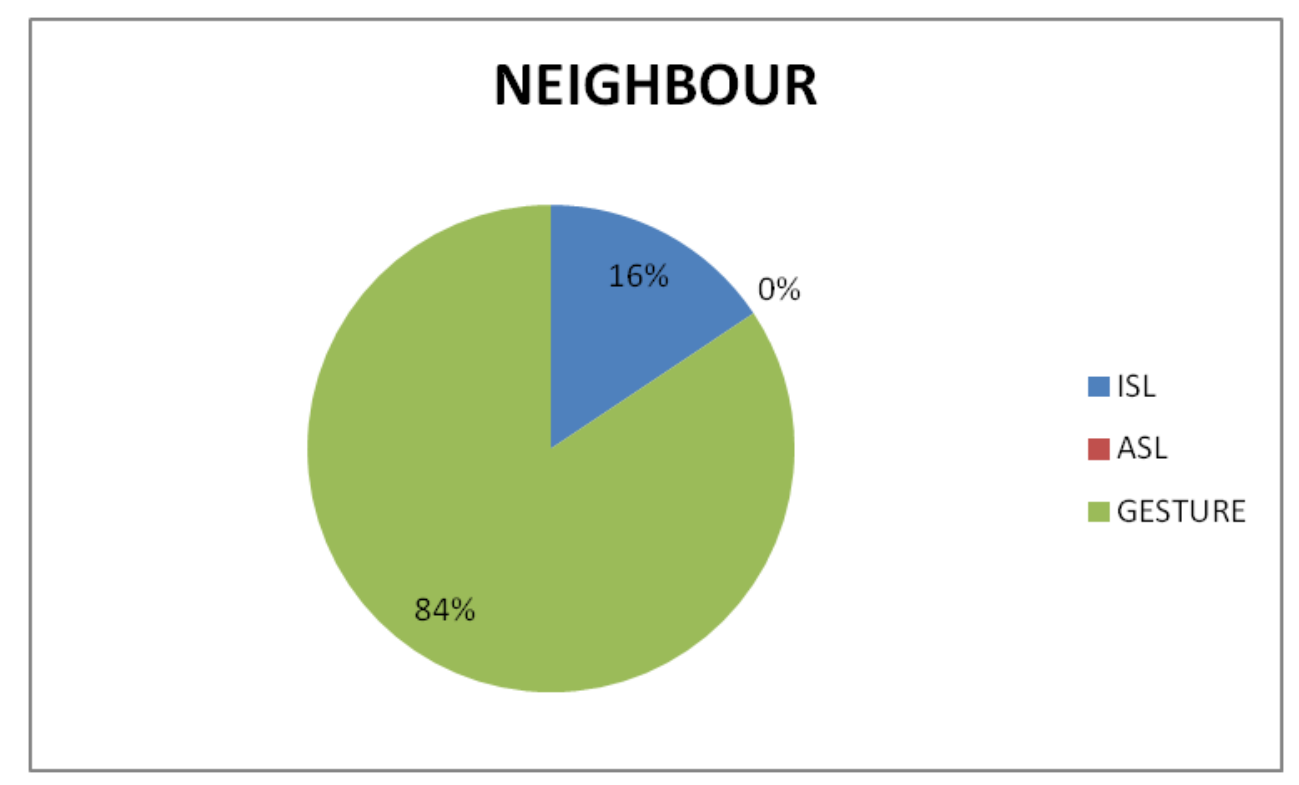

Fig: 10 Pie chart representing language use in neighbor domain.

$84 \%$ respondents said that they use gestures while communicating with their neighbors. Only $16 \%$ which is quite expected, given the deaf families live in mixed neighborhood, and hearing population is not trained in ISL. use ISL.

School:

Of all domains, school is the most complex domain because participants from different class, caste, gender, language, culture, ability level and motivation comes in contact. It forms a heterogeneous domain. The main participants of this domain are teachers and students. School is a domain which is very much committed to language management and development.

The first participant students vary in number of critical dimensions; such as age, gender, class and culture. Also they vary on the variety of language proficiency and the language beliefs they have learned from their home and neighborhood.

The second participant is teachers who are again vary on the basis of age, gender, class, training and language proficiency. 
There is a linguistic similarity and dissimilarity in this domain. It is full of linguistic and cultural diversity.

Table no 10: Summary of language use in school domain

\begin{tabular}{|c|c|c|c|c|}
\hline 20 & You Studied in? & 32 & & \\
\hline & a. $\quad$ Deaf School & & 24 & 75 \\
\hline & b. Normal School & & 8 & 25 \\
\hline 21 & Teachers were? & 32 & & \\
\hline & a. All Normal & & 20 & 63 \\
\hline & b. All Deaf & & 0 & 0 \\
\hline & c. Few Normal More Deaf & & 5 & 16 \\
\hline & d. Few Deaf More Normal & & 7 & 22 \\
\hline 22 & Your teacher often used what language? & 32 & & \\
\hline & a. ISL & & 5 & 16 \\
\hline & b. $\quad$ ASL & & 0 & 0 \\
\hline & c. GESTURES & & 27 & 84 \\
\hline 23 & You communicated with other students in? & 32 & & \\
\hline & a. $\quad$ ISL & & 23 & 72 \\
\hline & b. $\quad$ ASL & & 0 & 0 \\
\hline & c. GESTURES & & 9 & 28 \\
\hline 24 & In your class all students were? & 32 & & \\
\hline & a. ALL DEAF & & 27 & 84 \\
\hline & b. ALL HEARING & & 1 & 3 \\
\hline & c. $\quad$ FEW DEAF MORE HEARING & & 2 & 6 \\
\hline & $\begin{array}{ll}\text { d. } & \text { FEW HEARING MORE DEAF }\end{array}$ & & 2 & 6 \\
\hline
\end{tabular}




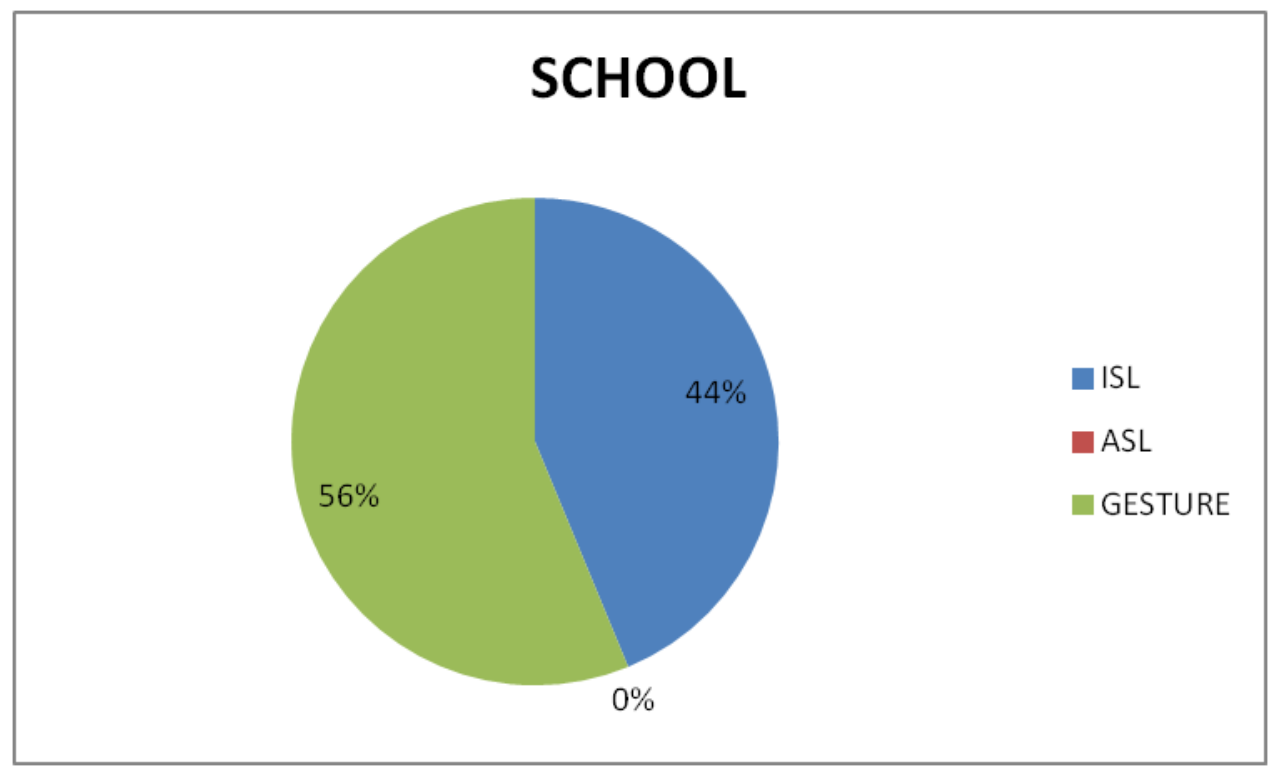

Fig: 11 Percentage of language use in School domain.

$44 \%$ of the respondents experienced use of ISL in schools, rest $56 \%$ experienced use of gestures in school. In India, there are very few sign language trained teachers due to which condition of deaf education is very poor in India. Deaf students communicate with their fellow students in ISL, but still gestures lip reading and oralism predominates in school domain.

Work Place:

With the establishment of various deaf associations, deaf people are trained to work in retail shops, different food chains. Government sectors also have reserved jobs for deaf. Deaf association also heir deaf people as sign language trainers. So, these deaf people work in an environment where both hearing and deaf people co-exist. How does a deaf communicate with its hearing boss and colleagues, how much ISL is used in this particular domain is interesting, because again it is a heterogeneous domain where people come from different background. 
Table no 11: Summary of language use at work place

\begin{tabular}{|c|c|c|c|c|}
\hline 29 & At your workplace are all? & 32 & & \\
\hline & a. $\quad$ DEAF & & 0 & 0 \\
\hline & b. $\quad$ HEARING & & 0 & 0 \\
\hline & c. $\quad$ FEW DEAF MORE HEARING & & 2 & 6 \\
\hline & $\begin{array}{ll}\text { d. } & \text { FEW HEARING MORE DEAF }\end{array}$ & & 8 & 25 \\
\hline & e. $\quad$ UNEMPLOYED & & 22 & 69 \\
\hline 30 & How your hearing staff communicate with you? & 32 & & \\
\hline & a. $\quad$ ISL & & 8 & 25 \\
\hline & b. $\quad$ ASL & & 0 & 0 \\
\hline & c. $\quad$ GESTURES & & 0 & 0 \\
\hline & WRITE & & 2 & 6 \\
\hline & e. $\quad \mathrm{NA}$ & & 22 & 69 \\
\hline 31 & How your deaf staffs communicate with you? & 32 & & \\
\hline & ISL & & 10 & 31 \\
\hline & ASL & & 0 & 0 \\
\hline & GESTURES & & 0 & 0 \\
\hline & WRITE & & 0 & 0 \\
\hline & NA & & 22 & 69 \\
\hline
\end{tabular}




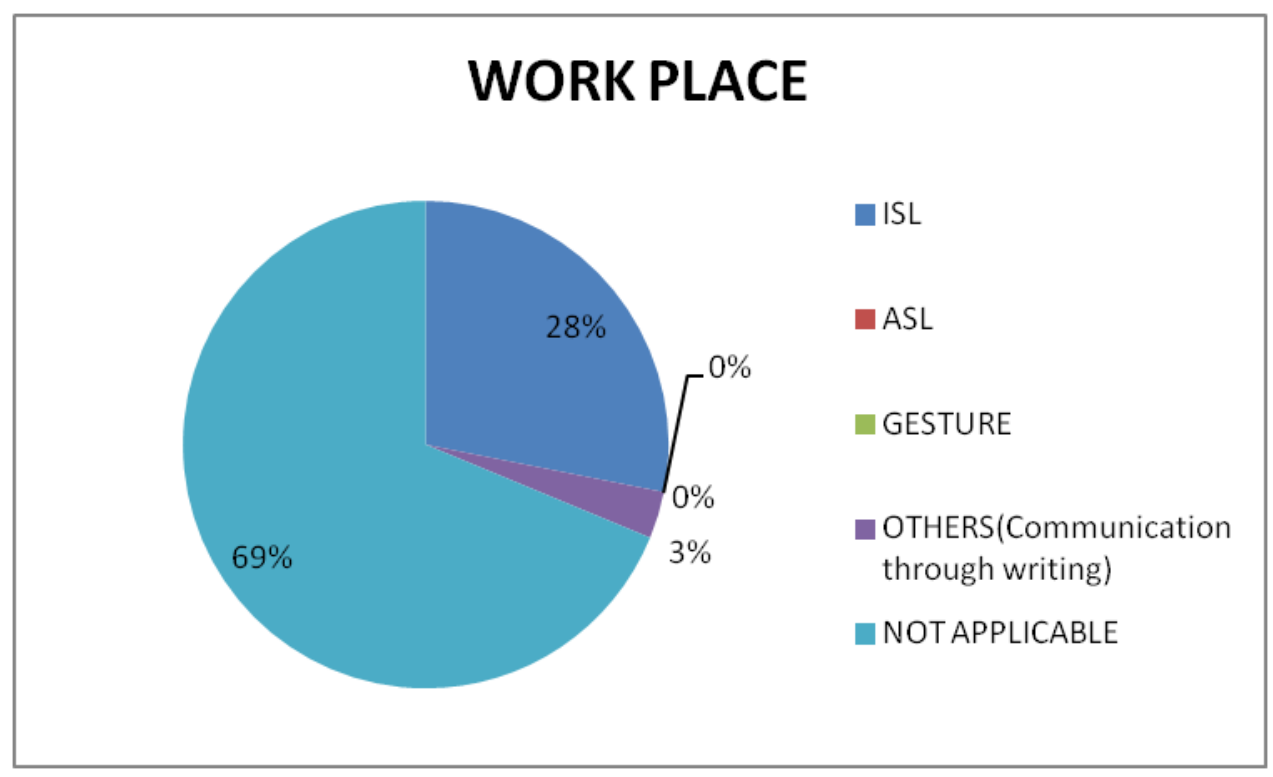

Fig: 12 Pie chart showing percentage of language use at work place.

$69 \%$ of the respondents were unemployed. So out of $30 \%$ of the employed respondents, $28 \%$ use ISL and 3\% respondents communicate by writing. At work places also, deaf face language issues due to the lack of sign language interpreters. The rest who work in deaf associations use ISL because their colleagues and boss are also deaf.

In the predictable mixed group domain ISL is the language which is predominantly used. In deaf association, we saw there was $100 \%$ use of ISL; the next domain in which the use of ISL dominates is the friend domain, where it is $84 \%$. It is followed by the family domain (45\%) and the school domain with $44 \%$.

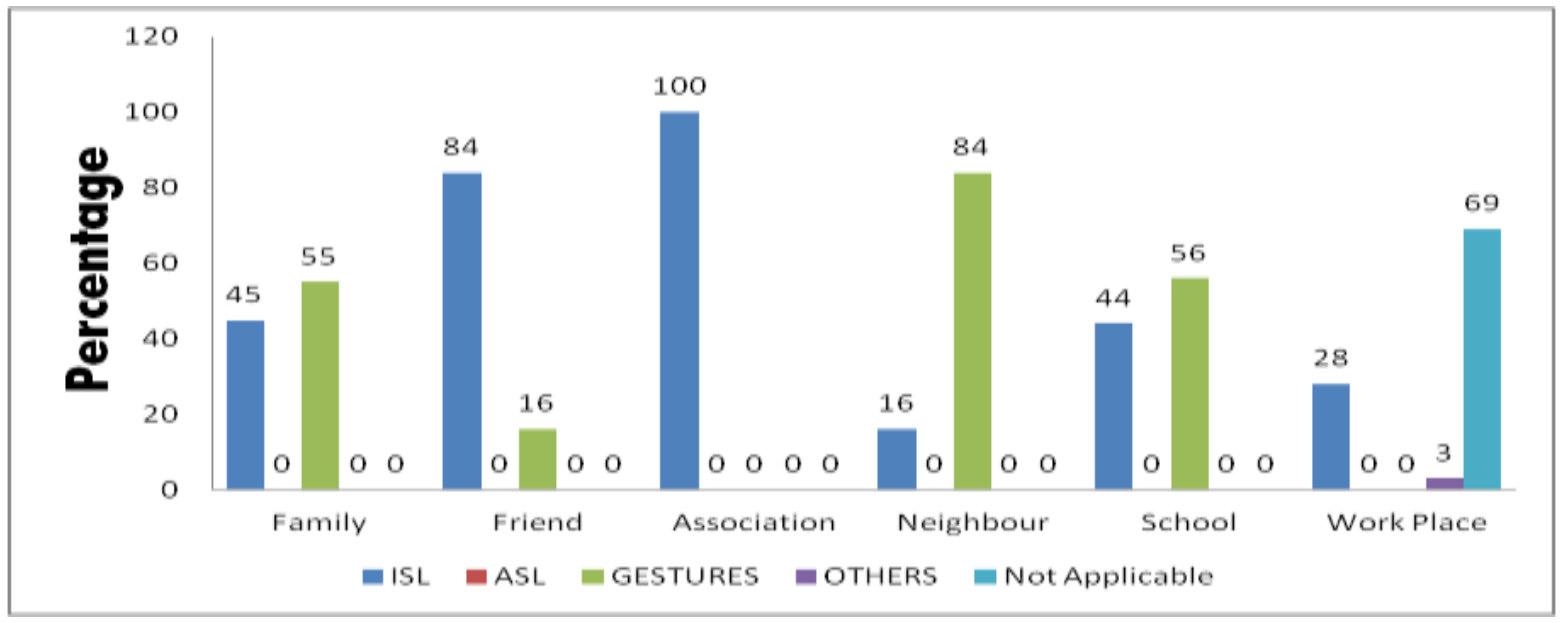

Fig: 12 Graph showing percentage of language used in predictable mixed group 


\subsubsection{Comparison between the two domains:}

This section investigates whether the setup of the domain affects people's choice of language use or not. In the unpredictable mixed group, the initiator and interlocutor are not well versed in each other's language, they don't know whether the initiator or interlocutor is deaf or not so the use of ISL is very low, almost nil in few domains like service providers. In this group, deaf people communicate by writing the details on piece of paper.

Whereas in the predictable mixed group domain, use of ISL dominates in all the domains. In deaf association $100 \%$ use of ISL was recorded. Respectively domains like family, friend and school help in the development and use of ISL.

Hence, we can say that language use by the deaf community is not stable. The use of language changes according to the setup, domain, initiator and interlocutor. The setup in which the initiator and interlocutor both are deaf was recorded with the $100 \%$ use of ISL, which is the association domain. The setup in which initiator and interlocutor do not know each other there the use of ISL was seldom for example in domain of government.

\section{Conclusion}

In this paper, the choice of language use was examined in nine domains. According to the use of ISL domains were categorized in two groups; the unpredictable mixed group (government, market and religious places) and predictable mixed group (family, friend, association, neighbor, school and work place). Use of ISL was recorded dominant in predictable mixed group; however, the dominance slightly differs from one domain to another. In unpredictable mixed group ISL use was the lowest.

The result shows that to build up intimate relation deaf people use ISL. This indicates that ISL has very strong vitality. Deaf people associate themselves with their language that is ISL. This result gives a positive answer to the question "Is ISL likely to be maintained in the 
foreseeable future?", the answer is yes because it used in their major domains like family, association, school and friends.

From the unpredictable mixed group results, it is clear that deaf people face communication issues. There are no trained ISL interpreters and even government officials don't know how to tackle with deaf people. In these domains, there is a need of language development and promotion programs. ISL awareness is required at these domains.

Another interesting finding in this study of language use and language contact of deaf community is that they have no contact mass media like television and radio. $78 \%$ of informants reported that they do not understand anything on TV and they don't watch it. The reason they don't understand anything is the news or shows which comes on TV have no subtitles. It is difficult for them to understand it without the help of an interpreter. $97 \%$ think that there should be few shows on TV in ISL. Mass media plays a vital role in language development but the deaf community is devoid of this benefit. 


\section{References}

Anand, Nisha. A Sociolinguistic study of the use of Indian Sign Language. M.Phil Thesis. Jawaharlal Nehru University. New Delhi. 2016.

Fishman, J. “Who speaks what language to whom and when?”. La Linguistique. 1965.

Fishman, J. Readings in the Sociology of Language. The Hague : Muton. 1968.

Fasold, R. The sociolinguistics of society. Oxford: Basil Blackwell. 1984.

Hymes, D.The ethnology of speaking. In J. Fishman (Ed.), Readings in sociology of language. The Hague: Mouton. 1968.

Hasseler. Studies in the History of the Language Science: History of Linguistics. John Benjamins publishing company. Philadelphia. 2008.

Jasper, J., Ostman J. \&Verschueren J. Society and Language Use: Pragmatics Highlight. Jon Benjamin publication. USA. 2010.

Sinha, Samar. A. Grammar of Indian Sign Language. PHD (Dissertation). Jawaharlal Nehru University. New Delhi. 2012.

Stokoe, William C. Sign Language Structure: An outline of the visual communication system of the American deaf. Studies in Linguistics, Occasional Papers 8. New York: University of Buffalo. 1960.

Vasishta, Madan, James Woodward \& Susan deSantis. Indian Sign Language. In J. V. van Cleve (ed.), Gallaudet Encyclopedia of Deaf People and Deafness 3. 79-81. New York: McGraw-Hill Book Company. 1987.

Woodward, J., Implications for sociolinguistic research among the deaf. Sign Language Studies. 1: 1-7. 1972.

Zeshan, Ulrike. 2003b. Indo-Pakistani Sign Language Grammar: A typological outline. Sign Language Studies 3.2: 157-212. 


\section{Appendix I}

\begin{tabular}{|l|l|l|}
\hline Sl. No. of & Title of Table & Page \\
\hline Table & List of domain studied & No 1 \\
\hline Table no 2 & Summary of language choice for each domain of & 3 \\
\hline Table no 3 & Summary of language use in government domain & $3-8$ \\
\hline Table no 4 & Summary of language use at market places & \\
\hline Table no 5 & Summary of language use at religious places & $9-10$ \\
\hline Table no 6 & Summary of language use in Family domain & 11 \\
\hline Table no 7 & Summary of language use in the friend domain & 12 \\
\hline Table no 8 & Summary of language use in Association domain & 15 \\
\hline Table no 9 & Summary of language use in neighbor domain & $18-17$ \\
\hline Table no 10 & Summary of language use in school domain & $21-22$ \\
\hline Table no 11 & Summary of language use at work place & \\
\hline
\end{tabular}

\begin{tabular}{|l|l|l|}
\hline Si. No. of & Title of Fig & Page \\
\hline Fig: 1 & Pie chart of percentage of language choice in all domains & No. \\
\hline Fig: 2 & Language use in nine domain & 8 \\
\hline Fig: 3 & Language use in government domain & 9 \\
\hline Fig: 4 & Pie chart of percentage of language use at market domain & 10 \\
\hline Fig: 5 & Pie chart of the percentage of language use at religious places & 11 \\
\hline Fig: 6 & Use of language use in unpredictable mixed group & 13 \\
\hline
\end{tabular}




\begin{tabular}{|l|l|l|}
\hline Fig: 7 & Language use at family domain & 16 \\
\hline Fig: 8 & Pie chart of the percentage of language use in friend domain & 17 \\
\hline Fig: 9 & Pie chart representing percentage of language use in Deaf & 18 \\
\hline Fig: 10 & Pie chart representing language use in neighbor domain & 19 \\
\hline Fig: 11 & Percentage of language use in School domain & 21 \\
\hline Fig: 12 & Graph showing percentage of language used in predictable mixed & 23 \\
\hline & group & \\
\hline
\end{tabular}

